
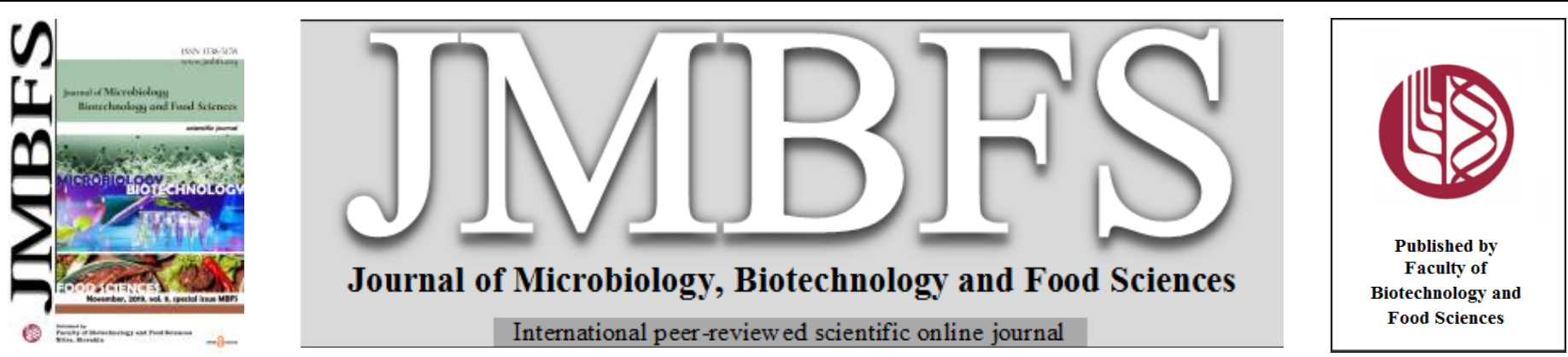

\title{
PROTEIN DEGRADATION AND FAT OXIDATION CHANGES IN SALTED MEAT PROCESSING
}

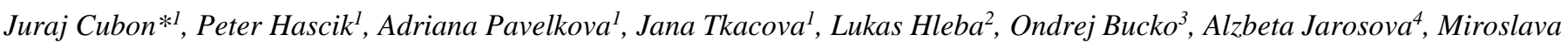 Cisarova ${ }^{5}$}

Address(es): prof. Ing. Juraj Čuboň, CSc.,

${ }^{1}$ Slovak University of Agriculture in Nitra, Faculty of Biotechnology and Food Science, Department of Technology and Quality of Animal Products, Tr. Andreja Hlinku 2, 94976 Nitra, Slovakia.

${ }^{2}$ Slovak University of Agriculture in Nitra, Faculty of Biotechnology and Food Science, Department of Microbiology, Tr. Andreja Hlinku 2, 94976 Nitra, Slovakia. ${ }^{3}$ Slovak University of Agriculture in Nitra, Faculty of Agrobiology and Food Resources, Department of Animal Husbandry, Tr. A. Hlinku 2, 94976 Nitra, Slovakia.

${ }^{4}$ Mendel University, Faculty of Agronomy, Department of Food Technology, Zemědělská 1, 61300 Brno, Czech Republic.

${ }^{5}$ University of SS. Cyril and Methodius, Faculty of Natural Sciences, Department of Biology, Nám. J. Herdu 2, Trnava, Slovakia.

*Corresponding author: juraj.cubon@uniag.sk

doi: 10.15414/jmbfs.2019.9.special.376-379

\section{ARTICLE INFO}

Received 2. 8. 2019

Revised 7. 10. 2019

Accepted 16. 10. 2019

Published 8. 11. 2019

Regular article OPEN OACCESS

\begin{abstract}
The study presents the results salted, smoked vacuum package pork meat during short maturation time. Samples were as fresh meat before salting, after salting and curing ( $7^{\text {th }}$ days), and after 28 days of maturation in vacuum package. The average fat content of the fresh semimembranosus muscle (SM) was $1.10 \mathrm{~g} .100 \mathrm{~g}^{-1}$ and in the fresh longissimus dorsi muscle (LDM) $5.58 \mathrm{~g}^{-100 \mathrm{~g}^{-1}}$. The SAFA content in fresh SM was $35.58 \mathrm{~g} .100 \mathrm{~g}^{-1}$ FAME and similar in the LDM was $35.08 \mathrm{~g}^{1} 100 \mathrm{~g}^{-1}$ FAME. The MUFA content in fresh SM was 50.18 g. $100 \mathrm{~g}^{-1}$ and in LDM was higher $51.29 \mathrm{~g} .100 \mathrm{~g}^{-1}$ FAME. The PUFA content in fresh SM was $13.28 \mathrm{~g}^{-100 \mathrm{~g}^{-1}}$ FAME and in LDM and was $13.56 \mathrm{~g} .100 \mathrm{~g}^{-1}$ FAME. The TVB-N content in fresh SM was $6.35 \mathrm{mg} \cdot 100 \mathrm{~g}^{-1}$, after 7 days of salting and curing was similar 6.61 $\mathrm{mg} .100 \mathrm{~g}^{-1}$ and after 28 days maturing increased to $19.65 \mathrm{mg} \cdot 100 \mathrm{~g}^{-1}$. The TVB-N content in the fresh LDM was $7.22 \mathrm{mg} .100 \mathrm{~g}^{-1}$, after 7 days of salting $7.58 \mathrm{mg} .100 \mathrm{~g}^{-1}$ and after 28 days of maturing increase to $22.09 \mathrm{mg} .100 \mathrm{~g}^{-1}$. The content of MDA in fresh SM was 0.056 mg.kg-1 after 7 days of salting and curing was similar $0.06 \mathrm{mg} \cdot \mathrm{kg}^{-1}$ and after 28 days of maturation increased to $0.11 \mathrm{mg} \cdot \mathrm{kg}^{-1}$. The content of MDA in the fresh LDM was $0.046 \mathrm{mg} \cdot \mathrm{kg}^{-1}$ after 7 days of salting $0.05 \mathrm{mg} \cdot \mathrm{kg}^{-1}$ and after 28 days of maturation process 0.09 $\mathrm{mg} \cdot \mathrm{kg}^{-1}$. The acid number in the fresh SM was $0.88 \mathrm{mg} \cdot \mathrm{KOH} \cdot \mathrm{g}^{-1}$, after 7 days of salting $2.15 \mathrm{mg} . \mathrm{KOH}_{\mathrm{g}} \mathrm{g}^{-1}$ and after 28 days of ripening $2.26 \mathrm{mg} . \mathrm{KOH} . \mathrm{g}^{-1}$. The acid number of fresh LDM was $1.13 \mathrm{mgKOH} . \mathrm{g}^{-1}$, after 7 days salting and curing $2.04 \mathrm{mgKOH}_{\mathrm{g}} \mathrm{g}^{-1}$ and after 28 days maturation $2.61 \mathrm{mgKOH} . \mathrm{g}^{-1}$. The peroxide number in the fresh SM was $0.58 \mathrm{mekvO}_{2} \cdot \mathrm{kg}^{-1}$, after 7 day salting $1.03 \mathrm{mekvO}_{2} \cdot \mathrm{kg}^{-1}$, and after 28 days maturation $2.23 \mathrm{mekvO}_{2} \cdot \mathrm{kg}^{-1}$. The peroxide number of fresh $\mathrm{LDM}$ was $0.59 \mathrm{mekvO}_{2} \cdot \mathrm{kg}^{-1}$, after 7 days salting 0.98 mekvO $2 \cdot \mathrm{kg}^{-1}$, and after 28 days maturation $5.31 \mathrm{mekvO}_{2} \cdot \mathrm{kg}^{-1}$.
\end{abstract}

Keywords: salted meat, MUFA, PUFA, SAFA, TVB-N, MDA, peroxide number

\section{INTRODUCTION}

Salted meats are products of meat group with typically textures and flavours. The processing of salted meats is traditional manufacturing practices consisting primarily of salting and drying steps, followed by a more or less extensive maturing period, which is dependent on the desired final product quality (Toldrá, 2016).

Traditional salted meats are product of exceptional quality product with a characteristic texture, flavour, color and palatability. These properties are gradually formed in a long production process involving salting, curing, and ripening steps.

The processing condition, humidity and temperature applied during maturing developed final characteristic properties of texture, flavour and colour (Mora et al., 2013).

The main biochemical reactions that occur during the processing of salted meats are enzymatic, including the hydrolysis of the muscle proteins (proteolysis), the hydrolysis of triacylglycerols and phospholipids (lipolysis) components.

Chemical reactions such as Maillard reactions, Strecker degradations and oxidative reactions developed the characteristic flavour. Salted meats undergo an intensive proteolysis during their processing. Products like salted ham, with a long period of maturing, show an extensive breakdown of main proteins and the generation of a high number of small peptides and finally, large amounts of free amino acids (FAA). The main biochemical reactions during salted meats processing, are taken to be the source of FAA. Proteolysis generally refers to enzyme of endogenous activity (Toldrá, 2009).

The macromolecular proteins and fats are degraded by endogenous enzymes to produce small peptides and aliphatic acids contributing to the unique flavour of cured meat products (Xing et al., 2016). Volatile organic compounds can also be produced through enzymatic and microbial activity which is likely to have adverse effect of the quality of the cured meat and human health. Proteolysis is by far the most biochemical phenomena during the dry-curing process (Jurado et al., 2007; Toldrá, 2009). This proces influences flavour and texture due to the degradation of protein to low-molecular weight compounds and FAA. FAA and biogenic amines influence directly in taste (Jurado et al., 2007; Buňka et al., 2013). Proteins can be gradually degraded into some toxic small-molecule elements including histamine, putrescine, tyramine, and tryptamine. Therefore, it is crucial to monitor the potential generation of the toxic components during the drying-ripening process. The amount of toxic components generated can be assessed by lot of indicators, such as the total volatile basic nitrogen (TVB-N) and content, the thiobarbituric acid reactive substances value (Khulal et al., 2016; Yang et al., 2017; Cuboň et al., 2019). Mainly TVB-N made up by the toxic small-molecule substances and non-protein nitrogenous compounds such as FAA and nucleotide catabolites, are considered as one of the most widely used indexes.

Temperature during processing significant influenced enzymes activity (Zhao et al., 2016). The ageing biceps femoris muscle, at $30^{\circ} \mathrm{C}$ compared with aged at $5{ }^{\circ} \mathrm{C}$ increased important intensity proteolysis. It has also been observed that high temperatures during the maturing process promote the creation of non-protein nitrogen components and, in turn, affect the proteolysis process (Ruiz-Ramírez, 2006).

The proteolysis remains stable during one week of storage at $30{ }^{\circ} \mathrm{C}$ and increases after one month of storage under the same conditions (Morales et al., 2007).

The anatomic location of muscles inside the semimembranosus muscle or biceps femoris muscle also plays an important role in the time course of proteolysis 
during the dry-cured ham process, owing to different salt and water transfer kinetics in each muscle (Harkouss et al., 2015).

Sodium chloride $(\mathrm{NaCl})$ is the most important ingredient in the process of salted meat for its contribution to the water-holding capacity (WHC), prevention of microbial growth, reduction of water activity and contributes to a typical desirable salty taste. Moreover, salt affects proteolysis, lipolysis and lipid oxidation which contribute to the development of typical flavour and texture (Lorenzo, 2015).

The low molecular mass peptides (between 1000 and $2100 \mathrm{Da}$ ) arise from both type of muscle proteins indicating that sarcoplasmic and myofibrillar proteins are affected during fermentation and ripening. Sequence analysis showed thus they could not be surely related to compounds of "good taste". The wide variety of cleavage products deduced from their positions on the parental protein suggested the complexity of proteolytic systems involved in their production. Four peptides originated from actin were obtained, which corresponding to the $\mathrm{N}$ terminal and central region of the actin. However, the three identified myosinderived peptides they are a cleavage product of the N-terminal (Fadda et al., 2010).

In reaction with molecular oxygen reactive peroxide radical is formed. This radical cleave hydrogen from another acid molecule forming hydroperoxide and another free radical (Estévez, 2017).

Lipid oxidation results in the formation of aldehydes. The most common aldehyde produced by damaging the polyunsaturated fatty acids is malondialdehyde (MDA). It is a simple alkandial derived from malonic acid (Singh et al., 2014).

Lipid oxidation is undesirable and is caused by either active lipoxygenase enzymes or through auto-oxidation. The product of the lipoxygenase enzyme activity is hydroperoxide of the fatty acids which promotes further oxidative reactions. The primary hydroperoxide and peroxide products are unrecognizable from the sensory point of assessment. The secondary products of the fat oxidation, such as aldehydes, ketones and epoxides, affect the sensory properties of the meat, especially odour and taste. Malodialdehyde (1,3propanedialcompound) is of particular importance (Liu et al., 2015; Toldrá et al., 2016).

Malodaldehyde is the product of peroxidation of polyunsaturated fatty acids. It is a genotoxic and very reactive substance (Kand'ár and Žáková, 2007).

The aim of the article was analysed protein degradation and fat oxidation changes in salted meat with short maturation time in the vacuum.

\section{MATERIAL AND METHODS}

The article presents the results salted, smoked pork meat during maturation time. Samples were monitored at time intervals, in fresh meat before salting, after salting and curing ( 7 days of maturation), and after 28 days of maturation in vacuum package.

For the purpose of experiment were used samples of semimembranosus muscle $(n=20)$ was taken from the thigh and a middle part of neck $(n=20)$ which is part of the longissimus dorsi muscle (at the level of $3^{\text {-rd }}-5^{\text {th }}$ thoracic vertebrae) After the salting process (7 days), the meat samples were smoked for 2 hours and analysed. After analysis, the samples were vacuum packed and stored at $4{ }^{\circ} \mathrm{C}$ for 28 days. Analyses of individual indicators were done parallel.

Determination of peroxide number was analysed by Cviková (2019) by titration method (STN ISO 3960: 2001).

The samples $(0.5$ to $2.9 \mathrm{~g})$ of fat (according to the expected peroxide number) were placed into a titration flask and add $25 \mathrm{~cm}^{3}$ of a mixture of glacial acetic acid and chloroform $(3: 2)$. Shake the flask until the fat is dissolved. Saturated potassium iodide solution $\left(1 \mathrm{~cm}^{3}\right)$ was added to via pipette; the flask is sealed and left to stir for 1 minute and left to stand in a dark place for 5 minutes after mixing. Subsequently, $75 \mathrm{~cm}^{3}$ of distilled water, $1 \mathrm{~cm}^{1}$ of a $2 \%$ starch solution was added. The precipitated iodine is titrated with a standard solution of sodium thiosulphate 0.01 mol. $\mathrm{L}^{-1}$ until the solution is discoloured. The sample was simultaneously analysed for the blank.

Acid value was determinate by titration method (STN 58 0100). The sample 5-10 $\mathrm{g}$ of animal fat was placed into the titration flask. Subsequently, the flask is immersed in a $70{ }^{\circ} \mathrm{C}$ water bath for several seconds. Subsequently $50 \mathrm{~cm}^{3}$ of a mixture of ethyl ether and 96\% ethanol in a 1: 1 ratio was added to the fat sample. The contents of the bank are gently shaken. The sample is titrated with a solution of $\mathrm{KOH}\left(\mathrm{c}=0.1 \mathrm{~mol} . \mathrm{L}^{-1}\right)$ using phenolphthalein as an indicator until pink for at least 10 seconds (Cviková, 2019).

Extraction of fat the sample for determination the peroxide number and acid value (so-called cold fat extraction). Sample of $10-35 \mathrm{~g}$ was placed into the 250 $\mathrm{ml}$ Erlenmeyer flask (according to the expected fat content of the sample), in a pan the sample is triturated with anhydrous sodium sulphate to a consistency of the bulk mixture. The fat was extracted from the mixture thus obtained using 100 $\mathrm{ml} / \mathrm{l}$ petroleter on a shaker for 30 minutes. The extract was filtered through filter paper with anhydrous sodium sulphate into a distillation flask. The solvent was removed from the distillation flask by evaporation in a vacuum rotary evaporator at $40{ }^{\circ} \mathrm{C}$. The extracted fat distillation flask was subsequently placed in an oven for $30 \mathrm{~min}$ at $102 \pm 2{ }^{\circ} \mathrm{C}$ and cooled in an oven to room temperature (about 20 $\mathrm{min})$. The extracted fat was used to analyse the acid number and peroxide number (Cviková, 2019).

Malondialdehyde (MDA) was determined by spectrophotometric method. The rate of secondary lipid oxidation in the meat is determined as the thiobarbitur number in $\mathrm{mg}$ malondialdehyde (MDA) per $\mathrm{kg}$ of salted meat. Sample preparation was performed according to (Marcinčák et al., 2004). To a $50 \mathrm{~cm}^{3}$ centrifuge tube was weighed $1.5 \mathrm{~g}$ of the meat or salted meat sample which was obtained from the same anatomical part during storage and $1 \mathrm{~cm}^{3}$ of ethylenediaminetetraacetic acid (EDTA) and $5 \mathrm{~cm}^{3}$ of $0.8 \%$ butylated hydroxytoluene (BHT) were added followed by gentle mixing. Just before homogenization, $8 \mathrm{~cm}^{3}$ of $5 \%$ trichloroacetic acid (TCA) was added. The homogenization was carried out for 30 seconds at $10,000 \mathrm{rpm}$. A laboratory homogenizer Diax 900 (Heidolph, Germany) was used and then centrifuged for 5 minutes $\left(3500 \mathrm{x} \mathrm{g}, 4^{\circ} \mathrm{C}\right)$ on a Universal 320 centrifuge (Hettich, Germany). After centrifugation, the top hexane layer was removed and the sample was filtered through Whatman 4 filter paper. The filtered sample was made up to $10 \mathrm{~cm}^{3}$ of 5\% TCA. Total $4 \mathrm{ml}$ samples were collected in a tube and $1 \mathrm{ml}$ of TBA was added. Malondialdehyde stock solution (MDA) is prepared by acid hydrolysis of 1,1,3,3-tetramethoxy propane (TMP). MDA standards were prepared from the stock solution. Both samples and standards were tempered in a water bath for 90 $\mathrm{min}$. at $70^{\circ} \mathrm{C}$. After cooling in an ice bath and tempering the samples for $45 \mathrm{~min}$. at room temperature, absorbance was measured on a UV-spectrophotometer UVmini-1240 (Shimazu, Japan) at $532 \mathrm{~nm}$. The data obtained were recalculated and the resulting MDA concentration was expressed in $\mathrm{mg} \cdot \mathrm{kg}^{-1}$ of meat.

Determination of total volatile bases nitrogenous (TVB-N) was analysed by vapor deposition and subsequent titration (Commission Regulation (EC) No 2074/2005). Methods for detecting total volatile nitrogenous bases (TVB-N) are usually analytical, such as a microdiffusion method and a semi-micro determination of crude protein. Volatile nitrogenous bases were extracted from the homogenized meat sample using a solution of 0.6 mol. $\mathrm{L}^{-1}$ of perchloric acid. After alkalization, the extract was distilled with water vapour and the volatile alkaline components were absorbed by the acid absorbent collection tank. The TVB-N concentration was determined by titration of absorbed basic substances using a Tashiro indicator. The titration of the solution in the hydrochloric acid collection vessel was used to calculate the TVB-N concentration (Cviková, 2019).

\section{Statistical analysis}

The data were statistical analysed by the program SAS 9.3, using the application Enterprise Guide 4.2.

\section{RESULTS AND DISCUSSION}

Degradation metabolites: malondialdehyde, TVB-N, acidity and peroxide numbers in fresh pork leg (semimembranosus muscle) and pork neck (longissimus dorsi muscle), after 7 days of salting and after 28 days of maturing in the vacuum package were analysed.

The average fat content of the fresh semimembranosus muscle was $1.10 \mathrm{~g} .100 \mathrm{~g}^{-1}$

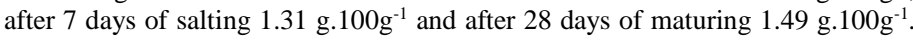
Table 1 presents the changes in fatty acid content of the semimembranosus muscle in the salting and shortened maturation process. The average content of saturated fatty acids (SAFA) in fresh semimembranosus muscle was 35.58 g. $100 \mathrm{~g}^{-1}$ FAME, after 7 days of salting 36.21 g. $100 \mathrm{~g}^{-1}$ FAME and after 28 days of maturing 36.33 g. $100 \mathrm{~g}^{-1}$ FAME (Table 1). The average content of monounsaturated fatty acids (MUFA) in fresh semimembranosus muscle was 50.18 g. $100 \mathrm{~g}^{-1}$ FAME, after 7 days of salting 49.97 g. $100 \mathrm{~g}^{-1}$ FAME and after 28 days of maturation process $49.93 \mathrm{~g} \cdot 100 \mathrm{~g}^{-1}$ FAME. The average content of polyunsaturated fatty acids (PUFA) in fresh semimembranosus muscle was 13.28 g. $100 \mathrm{~g}^{-1}$ FAME, after 7 days of salting 13.81 g. $100 \mathrm{~g}^{-1}$ FAME and after 28 days of maturing $13.5 \mathrm{~g} .100 \mathrm{~g}^{-1}$ FAME.

Table 1 Fatty acids contents (g.100g $\mathrm{g}^{-1} \mathrm{FAME}$ ) in salted ham (semimembranosus muscle) during processing time (mean $\pm \mathrm{SE}$ )

\begin{tabular}{lccc} 
Parameter & Fresh semimembranosus muscle & $\begin{array}{c}\text { Semimembranosus muscle after 7 days of } \\
\text { salting }\end{array}$ & $\begin{array}{c}\text { Semimembranosus muscle after } \\
\text { 28 days of maturing }\end{array}$ \\
\hline $\mathbf{3} \boldsymbol{\omega}$ acids & $0.63 \pm 0.03$ & $0.59 \pm 0.04$ & $0.55 \pm 0.01$ \\
\hline 6 $\boldsymbol{\omega}$ acids & $12.94 \pm 0.49$ & $13.79 \pm 0.32$ & $14.76 \pm 0.77$ \\
\hline MUFA & $50.18 \pm 2.15$ & $49.97 \pm 0.67$ & $49.93 \pm 0.65$ \\
\hline PUFA & $13.28 \pm 0.32$ & $13.81 \pm 0.51$ & $13.81 \pm 2.60$ \\
\hline SAFA & $35.58 \pm 0.81$ & $36.21 \pm 1.53$ & $36.33 \pm 0.47$ \\
\hline
\end{tabular}


The average SAFA content was in fresh semimembranosus muscle $35.58 \mathrm{~g} .100 \mathrm{~g}$ ${ }^{1}$ FAME and $36.21 \mathrm{~g} .100 \mathrm{~g}^{-1}$ FAME after 7 days of salting. The average MUFA content was $50.18 \mathrm{~g} .100 \mathrm{~g}^{-1}$ FAME in fresh semimembranosus muscle and 49.97 g. $100 \mathrm{~g}^{-1}$ FAME after 7 days of salting and aging. The average PUFA content was 14.28 g. $100 \mathrm{~g}^{-1}$ FAME in fresh semimembranosus muscle and $13.81 \mathrm{~g} .100 \mathrm{~g}^{-1}$ FAME after 7 days of salting and aging. The average MUFA content was 13.81 g. $100 \mathrm{~g}^{-1}$ FAME after 7 days of salting and 13.5 g. $100 \mathrm{~g}^{-1}$ FAME after 28 days of maturation process. The differences in the individual fatty acid content were probably influenced by the fact that each sample was a different cut of technological part of meat.

Table 2 Fatty acid content (g. $100 \mathrm{~g}^{-1} \mathrm{FAME}$ ) in neck (longissimus dorsi muscle) during processing time (mean $\pm \mathrm{SE}$ )

\begin{tabular}{lccc}
\hline Parameter & Fresh longissimus dorsi muscle & $\begin{array}{c}\text { Longissimus dorsi muscle after 7 days of } \\
\text { salting }\end{array}$ & $\begin{array}{c}\text { Longissimus dorsi muscle after } \\
\text { 28 days of maturing }\end{array}$ \\
\hline $\mathbf{3} \boldsymbol{\omega}$ acids & $0.75 \pm 0.05$ & $0.64 \pm 0.05$ & $0.66 \pm 1.23$ \\
\hline 6 $\omega$ acids & $9.26 \pm 1.10$ & $10.94 \pm 1.56$ & $11.64 \pm 0.75$ \\
\hline MUFA & $51.29 \pm 2.18$ & $49.81 \pm 10.70$ & $49.81 \pm 2.43$ \\
\hline PUFA & $13.56 \pm 0.88$ & $13.45 \pm 1.93$ & $13.2 \pm 1.28$ \\
\hline SAFA & $35.08 \pm 1.73$ & $35.99 \pm 1.36$ & $35.76 \pm 0.01$ \\
\hline
\end{tabular}

The average fat content of the fresh longissimus dorsi muscle was $5.58{\mathrm{~g} .100 \mathrm{~g}^{-1}}^{-}$

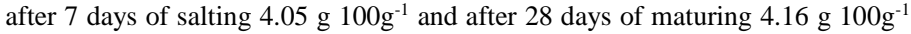

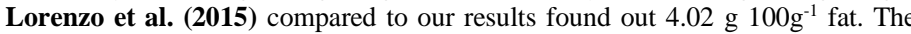
differences between fat contents in different stage of process are affected by different cut of longissimus dorsi muscle. Table 2 presents the changes in fatty acid content of the longissimus dorsi muscle in the salting and shortened maturation process. The average saturated fatty acid content (SAFA) in the

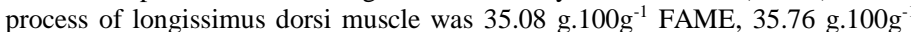
FAME and $35.99 \mathrm{~g} .100 \mathrm{~g}^{-1}$ FAME, respectively. The average content of MUFA

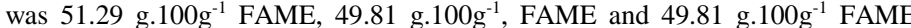
respectively. The content of PUFA in longissimus dorsi muscle was 13.56

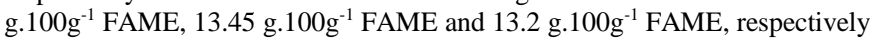

The content of SAFA in longissimus dorsi muscle was 35.08 g.100g-1 FAME (fresh meat), 35.99 g. $100 \mathrm{~g}^{-1}$ FAME (after salting), and 35.76 g.100 ${ }^{-1}$ FAME

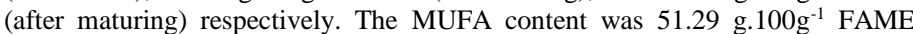

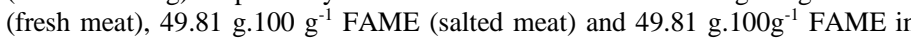
the matured longissimus dorsi muscle.

The average PUFA content was $13.56 \mathrm{~g} .100 \mathrm{~g}^{-1}$ FAME (in fresh longissimus dorsi

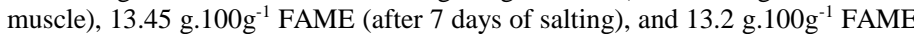
(after maturing).

Jiménez-Colmenero et al. (2010) found comparable SAFA contents (35-40 g. $100 \mathrm{~g}^{-1}$ FAME), content of MUFA (45-50 g. $100 \mathrm{~g}^{-1}$ FAME) and PUFA content (10-15 g.100 $\mathrm{g}^{-1}$ FAME) in salted pork ham (Iberian ham).

Table 3 Content of TVB-N, malondialdehyde, acid number, peroxide number (mean $\pm \mathrm{SE}$ ) in the fresh ham (semimembranosus muscle) and the neck (longissimus dorsi muscle)

\begin{tabular}{lccc}
\hline Parameter & Semimembranosus muscle & Longissimus dorsi muscle & t-test \\
\hline TVB-N $\left(\mathbf{m g . 1 0 0 g}^{-1}\right)$ & $6.35 \pm 0.36$ & $7.22 \pm 1.34$ & ++ \\
\hline MDA (mg.kg-1) & $0.056 \pm 0.02$ & $0.046 \pm 0.005$ & + \\
\hline Acid number $\left(\mathbf{m g K O H . g}^{-1}\right)$ & $0.88 \pm 0.20$ & $1.13 \pm 0.26$ & ++ \\
\hline Peroxide number $\left(\mathbf{m e k v O}_{\mathbf{2}} \cdot \mathbf{k g}^{-1}\right)$ & $0.58 \pm 0.11$ & $0.59 \pm 0.19$ & - \\
\hline
\end{tabular}

The TVB-N content in the fresh semimembranosus muscle before salting was $6.35 \mathrm{mg} .100 \mathrm{~g}^{-1}$ and $7.22 \mathrm{mg} \cdot 100 \mathrm{~g}^{-1}$ in the fresh longissimus dorsi muscle (Table $3)$. The difference was statistically highly evident $(\mathrm{p} \leq 0.01)$. The content of malondialdehyde (MDA) in fresh semimembranosus muscle was statistically significant $(\mathrm{p} \leq 0.05)$ higher $0.056 \mathrm{mg} \cdot \mathrm{kg}^{-1}$ compared to fresh longissimus dorsi muscle $0.046 \mathrm{mg} \cdot \mathrm{kg}^{-1}$. The acidic number in the fresh semimembranosus muscle prior to salting was statistically highly significant $(\mathrm{p} \leq 0.01) 0.88 \mathrm{mg} \mathrm{KOH.g}$ compared to the longissimus dorsi muscle $\left(1.13 \mathrm{mg} \mathrm{KOH} . \mathrm{g}^{-1}\right)$. The peroxide number was not significantly higher in the fresh longissimus dorsi muscle $(0.59$ mekvO $\left.2 \cdot \mathrm{kg}^{-1}\right)$ compared to the fresh semimembranosus muscle $\left(0,58 \mathrm{mekvO}_{2} \cdot \mathrm{kg}\right.$ $\left.{ }^{1}\right)$.

Table 4 Content of TVB-N, malondialdehyde, acid number, peroxide number (mean \pm SE) after 7 days of salting ham (semimembranosus muscle) and neck (longissimus dorsi muscle)

\begin{tabular}{llll}
\hline Parameter & Semimembranosus muscle & Longissimus dorsi muscle & t-test \\
\hline TVB-N $\left(\mathbf{m g . 1 0 0 g}^{-1}\right)$ & $6.61 \pm 0.41$ & $7.58 \pm 0.97$ & +++ \\
\hline MDA $\left(\mathbf{m g . k g}{ }^{-1}\right)$ & $0.06 \pm 0.004$ & $0.05 \pm 0.01$ & + \\
\hline Acid number $\left(\mathbf{m g K O H . g}^{-1}\right)$ & $2.15 \pm 0.59$ & $2.04 \pm 0.51$ & - \\
\hline Peroxide number $\left(\mathbf{m e k v O}_{\mathbf{2}} \cdot \mathbf{k g}^{-1}\right)$ & $1.03 \pm 0.31$ & $0.98 \pm 0.29$ & - \\
\hline
\end{tabular}

The average TVB-N content (Table 4) in the salted and cured semimembranosus muscle was statistically significant $(\mathrm{p} \leq 0.001)$ lower $\left(6.61 \mathrm{mg}^{-100 \mathrm{~g}^{-1}}\right)$ compared to the salted longissimus dorsi muscle $\left(7.58 \mathrm{mg} 100 \mathrm{~g}^{-1}\right)$. Malondialdehyde content in the semimembranosus muscle after 7 days of salting and smoking was statistically significantly higher $(\mathrm{p} \leq 0.05) 0.06 \mathrm{mg} \cdot \mathrm{kg}^{-1}$ than in salted longissimus dorsi muscle $0.05 \mathrm{mg} \cdot \mathrm{kg}^{-1}$. Fan et al. (2019) reported higher malondialdehyde content $\left(0.66 \mathrm{mg} . \mathrm{kg}^{-1}\right)$ compared to our results after 5 days of storage in semimembranosus muscle. Also Hansen et al. (2004) found a higher malondialdehyde content of $0.3 \mathrm{mg} \cdot \mathrm{kg}^{-1}$ in longissimus dorsi muscle after 6 days of cold storage at $3{ }^{\circ} \mathrm{C}$ compared to our results, but in fresh not salted meat.

The acid number was $2.15 \mathrm{mg} \mathrm{KOH} . \mathrm{g}^{-1}$ in the semimembranosus muscle and 2.04

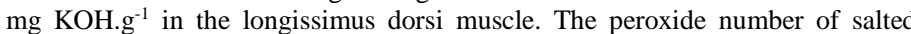
longissimus dorsi muscle was no significantly lower $\left(0.98\right.$ mekvO $\left.2 \cdot \mathrm{kg}^{-1}\right)$ compared to salted semimembranosus muscle $\left(1.03 \mathrm{mekvO}_{2} \cdot \mathrm{kg}^{-1}\right)$.

Table 5 Content of TVB-N, malondialdehyde, acid number, peroxide number (mean \pm SE) after 28 days of maturation ham (semimembranosus muscle) and neck (longissimus dorsi muscle)

\begin{tabular}{llll}
\hline Parameter & Semimembranosus muscle & Longissimus dorsi muscle & t-test \\
\hline TVB-N $\left(\mathbf{m g . 1 0 0 g}^{-1}\right)$ & $19.65 \pm 1.40$ & $22.09 \pm 1.79$ & +++ \\
\hline MDA $\left(\mathbf{m g . k g}{ }^{-1}\right)$ & $0.11 \pm 0.02$ & $0.09 \pm 0.01$ & ++ \\
\hline Acid number $\left(\mathbf{m g K O H . \mathbf { g } ^ { - 1 }}\right)$ & $2.26 \pm 1.04$ & $2.61 \pm 0.88$ & - \\
\hline Peroxide number $\left(\mathbf{m e k v O}_{\mathbf{2}} \cdot \mathbf{k g}^{-\mathbf{1}}\right)$ & $2.23 \pm 0.39$ & $5.31 \pm 4.10$ & ++ \\
\hline
\end{tabular}

The average content of TVB-N (total volatile bases of nitrogen) in salted semimembranosus muscle after 28 days of maturation was significantly $(\mathrm{p} \leq 0.001)$ lower $19.65 \mathrm{mg} \cdot 100 \mathrm{~g}^{-1}$ than in the longissimus dorsi muscle 22.09 mg.100 $\mathrm{g}^{-1}$ (Table 5). Approximate results reported Li et al. (2019) TVB-N content in fresh pork meat $9.42 \mathrm{mg} .100 \mathrm{~g}^{-1}$ and increase to $19.57 \mathrm{mg} .100 \mathrm{~g}^{-1}$ after 13 days, the samples were stored at $4{ }^{\circ} \mathrm{C}$. Comparable results of TVB-N contents
(24.2 mg. $\left.100 \mathrm{~g}^{-1}\right)$ presents Li et al. (2015) in pork ham packed under vacuum and stored at $5{ }^{\circ} \mathrm{C}$. Similar contents of the TVB-N $\left(6.8 \mathrm{mg} .100 \mathrm{~g}^{-1}\right)$ presents Lee et al. (2018) in fresh meat but compared to our results at 22 days presents markedly higher content of TNB-N $49.1 \mathrm{mg} .100 \mathrm{~g}^{-1}$. The malondialdehyde (MDA) content in the salted semimembranosus muscle after 28 days of maturation was significantly $(\mathrm{p} \leq 0.01)$ higher $\left(0.11 \mathrm{mg} \cdot \mathrm{kg}^{-1}\right)$ compared to the longissimus dorsi 
muscle $\left(0.09 \mathrm{mg} \cdot \mathrm{kg}^{-1}\right)$. The acid number in the salted semimembranosus muscle after 28 days of maturation was $2.26 \mathrm{mg} \mathrm{KOH.g}{ }^{-1}$ and $2.61 \mathrm{mg} \mathrm{KOH.g}{ }^{-1}$ in the longissimus dorsi muscle.

The peroxide number in the salted semimembranosus muscle after 28 days of maturation was 2.23 mekv. $\mathrm{O}_{2} \cdot \mathrm{kg}^{-1}$ and statistically significant high $(\mathrm{p} \leq 0.01)$ in the longissimus dorsi muscle $\left(5.31 \mathrm{mekv} \cdot \mathrm{O}_{2} \cdot \mathrm{kg}^{-1}\right)$.

\section{CONCLUSION}

The paper analysed the fat oxidation and protein degradation of vacuum package salted meat with reduced maturation time of 28 days. To compare the quality of salted meat produced three maturing phases were selected, fresh meat, salted and smoked meat after 7 days of salting and curing and after 28 days of shortened maturation in vacuum. The composition of SAFA, MUFA and PUFA were id the semimembranosus muscle and longissimus dorsi muscle similar.

The TVB-N content significantly increased after 28 days of maturing time in both muscles. The content of MDA significantly increased in maturing time in both muscles. The acid number increase in both muscles in salting time. The peroxide number gradually increased in both muscles.

The salting time of 7 days at a salt concentration of $10 \%$ and maturing in the vacuum package is sufficient only for the semimembranosus muscle (ham) but is not sufficient to produce salted meat with shorted maturing time for the longissimus dorsi muscle (neck).

Acknowledgment: The scientific monograph was implemented with the support of the KEGA 027SPU-4/2019 and APVV-18-0312 projects.

\section{REFERENCES}

Buňka, F., Budinský, P., Zimáková, B., Merhaut, M., Flasarová, R., Pachlová, V., ... \& Buňková, L. (2013). Biogenic amines occurrence in fish meat sampled from restaurants in region of Czech Republic. Food Control, 31(1), 49-52. https://doi.org/10.1016/j.foodcont.2012.09.044

Čuboň, J., Haščík, P., Hleba, L., Cviková, P., Tkáčová, J., Lopašovský, L., \& Pavelková, A. (2019). Biogenic Amines as Risk Factors of Food Chain. Archives of Ecotoxicology, 1(1), 7-10.

Cviková, P. 2019. Degradačné procesy v solených mäsách. SAU Nitra Dizertačná práca, $142 \mathrm{p}$.

Estévez, M. 2017. What's New in Meat Oxidation?. In PURSLOW, P. P. New aspect of meat quality - from genes to ethics. Elsevier: Woodhead publishing, p 465-477. ISBN 978-0-08-100600-9.

Fadda, S., López, C., \& Vignolo, G. (2010). Role of lactic acid bacteria during meat conditioning and fermentation: peptides generated as sensorial and hygienic $\begin{array}{llll}\text { biomarkers. } & \text { Meat } & \text { science, } & \text { 66-79. }\end{array}$ https://doi.org/10.1016/j.meatsci.2010.04.023

Fan, X. J., Liu, S. Z., Li, H. H., He, J., Feng, J. T., Zhang, X., \& Yan, H. (2019). Effects of Portulaca oleracea L. extract on lipid oxidation and color of pork meat during refrigerated storage. Meat science, 147, 82-90. https://doi.org/10.1016/j.meatsci.2018.08.022

Hansen, E., Juncher, D., Henckel, P., Karlsson, A., Bertelsen, G., \& Skibsted, L. H. (2004). Oxidative stability of chilled pork chops following long term freeze $\begin{array}{llll}\text { storage. } & \text { Meat } & \text { Science, } & \text { 68(3), }\end{array}$ https://doi.org/10.1016/j.meatsci.2004.05.002

Harkouss, R., Astruc, T., Lebert, A., Gatellier, P., Loison, O., Safa, H., ... \& Mirade, P. S. (2015). Quantitative study of the relationships among proteolysis, lipid oxidation, structure and texture throughout the dry-cured ham process. Food chemistry, 166, 522-530.

http://dx.doi.org/10.1016/j.foodchem.2014.06.013

Jiménez-Colmenero, F., Ventanas, J., \& Toldrá, F. (2010). Nutritional composition of dry-cured ham and its role in a healthy diet. Meat Science, 84(4), 585-593. https://doi.org/10.1016/j.meatsci.2009.10.029

Jurado, Á., García, C., Timón, M. L., \& Carrapiso, A. I. (2007). Effect of ripening time and rearing system on amino acid-related flavour compounds of $\begin{array}{llll}\text { Iberian ham. } & \text { Meat } & \text { Science, } & \text { 75(4), }\end{array}$ http://dx.doi.org/10.1016/j.meatsci.2006.09.006.

Kand'ár, R., Žáková, P. 2007. Monitorování oxidačního stresu pomocí kapalinové chromatografie. CHEMagazín 5, 8-11, 2007.

Khulal, U., Zhao, J., Hu, W., \& Chen, Q. (2016). Nondestructive quantifying total volatile basic nitrogen (TVB-N) content in chicken using hyperspectral imaging (HSI) technique combined with different data dimension reduction $\begin{array}{llll}\text { algorithms. Food } & \text { chemistry, } & 197, & 1191-199\end{array}$ https://doi.org/10.1016/j.foodchem.2015.11.084

Lee, H., Kim, M. S., Lee, W. H., \& Cho, B. K. (2018). Determination of the tota volatile basic nitrogen (TVB-N) content in pork meat using hyperspectral fluorescence imaging. Sensors and Actuators B: Chemical, 259, 532-539. https://doi.org/10.1016/j.snb.2017.12.102

Li, H., Chen, Q., Zhao, J., \& Wu, M. (2015). Nondestructive detection of total volatile basic nitrogen (TVB-N) content in pork meat by integrating hyperspectral imaging and colorimetric sensor combined with a nonlinear data fusion. LWT-Food Science and Technology, 63(1), 268-274 https://doi.org/10.1016/j.lwt.2015.03.052

Li, Y., Tang, X., Shen, Z., \& Dong, J. (2019). Prediction of total volatile basic nitrogen (TVB-N) content of chilled beef for freshness evaluation by using viscoelasticity based on airflow and laser technique. Food chemistry, 287, 126 132. https://doi.org/10.1016/j.foodchem.2019.01.213

Liu, Y., Zhang, R. Y., Zhao, J., Dong, Z., Feng, D. Y., Wu, R., ... \& Zhao, G. (2015). Ginsenoside Rd protects SH-SY5Y cells against 1-methyl-4 phenylpyridinium induced injury. International journal of molecular sciences, 16(7), 14395-14408. https://doi.org/10.3390/ijms160714395

Lorenzo, J. M., Fonseca, S., Gómez, M., \& Domínguez, R. (2015). Influence of the salting time on physico-chemical parameters, lipolysis and proteolysis of drycured foal "cecina". LWT-Food Science and Technology, 60(1), 332-338. http://dx.doi.org/10.1016/j.lwt.2014.07.023

Marcinčák, S. - Sokol, J. - Bystrický, P. et al. 2004. Determination of lipid oxidation level in broiler meat by liquid chromatography. J AOAC Int 2004; 87 (5): 1148-52.

Mora, L., Fraser, P. D., \& Toldrá, F. (2013). Proteolysis follow-up in dry-cured meat products through proteomic approaches. Food research international, 54(1), 1292-1297.

http://dx.doi.org/10.1016/j.foodres.2012.09.042

Morales, R., Serra, X., Guerrero, L., \& Gou, P. (2007). Softness in dry-cured porcine biceps femoris muscles in relation to meat quality characteristics and processing conditions. Meat Science, 77(4), 662-669. https://doi.org/10.1016/j.meatsci.2007.05.020

Ruiz-Ramírez, J., Arnau, J., Serra, X., \& Gou, P. (2006). Effect of pH24, NaCl content and proteolysis index on the relationship between water content and texture parameters in biceps femoris and semimembranosus muscles in dry-cured ham. Meat Science, 72(2), 185-194.

https://doi.org/10.1016/j.meatsci.2005.06.016

SAS (2008) 9.3 Enhanced Logging Facilities, Cary, NC: SAS Institute Inc., 2008 Toldrá, F., Mora, L., \& Reig, M. (2016). New insights into meat by-product $\begin{array}{llrr}\text { utilization. } & \text { Meat } & \text { science, } & \text { 54-59. }\end{array}$ https://doi.org/10.1016/j.meatsci.2016.04.021

Toldrá, F. 2016. Ham: Dry-cured Ham. Encyclopedia of food and health, p. $307-$ 310. https://doi.org/10.1016/b978-0-12-384947-2.00368-8

Xing, L. J., Hu, Y. Y., Hu, H. Y., Ge, Q. F., Zhou, G. H., \& Zhang, W. G. (2016) Purification and identification of antioxidative peptides from dry-cured Xuanwei ham. Food Chemistry, $194, \quad 951-958$ https://doi.org/10.1016/i.foodchem.2015.08.101

Yang, Q., Sun, D. W., \& Cheng, W. (2017). Development of simplified models for nondestructive hyperspectral imaging monitoring of TVB-N contents in cured meat during drying process. Journal of food engineering, 192, 53-60. https://doi.org/10.1016/j.jfoodeng.2016.07.015

Zhao, Y., Abbar, S., Amoah, B., Phillips, T. W., \& Schilling, M. W. (2016) Controlling pests in dry-cured ham: A review. Meat science, 111, 183-191. http://dx.doi.org/10.1016/j.meatsci.2015.09.009 